\section{Globalization and Imperialism}

\section{TO THE EDITOR:}

PMLA's admirable and instructive January issue, Globalizing Literary Stadies (116 [2001]: 1272), seems in some danger of bypassing itself. Of the thirteen contributors, eleven hold positions in American universities. This is understandable given the nature of the MLA membership. More important, the hundreds of items cited in the several bibliographies include relatively few originating outside the United States and Britain. Of these, a large proportion are from Central and South America. Paul Jay ("Beyond Discipline? Globalization and the Future of English" 46n9) comments adversely on male predominance in global studies, noting that in the recent collection of essays The Cultures of Globalization only three of the eighteen contributors are women. This trend is reinforced in January's PMLA, in which ten of the thirteen contributors are male. That inequality is symptomatic of a much more massive exclusion brought about, paradoxically, under the banner of inclusiveness (Rey Chow, "How [the] Inscrutable Chinese Led to Globalized Theory" 69).

Globalizing literary studies is not the same thing as globalizing the study of English. Jay makes no attempt to distinguish between the two. Others who may see them as distinct make no attempt to examine the location of the latter in the former. Globalized English studies is an obvious successor to Commonwealth literature, and Commonwealth literature has been clogged by an imperial sediment that caused Amitav Ghosh to withdraw his latest novel from consideration for a Commonwealth Award. Substituting English-speakingness for Englishness is an expansionist, imperial move that marginalizes other languages in which much of our civilizational heritage is embedded.

Saying this brings me to another main evasion in this issue. Apart from Edward Said, none of the contributors makes any real attempt to connect globalism with imperialism. Some attention is given to whether globalism is modern, postmodern, or as ancient as time itself (Giles Gunn, Introduction $20-$ 21; Jay 35). But imperialism is also almost as old as time. Empires have often dreamed of universality. Globalization appropriates this dream. Its rhetoric calls for a universal meritocracy that offers equality of opportunity to all the world's peoples. Combined with the denial of an outside (all nations that wish to) enter are encouraged to do so), this call enables global propagandists to claim that the ome world they envision is not imperialist. It is simply subject everywhere to the same rules. Who invents the rules is immaterial. The point is that they are enfored without discrimination.

One is entitled to see in this leveled (or bull-dozed) playing field another and pertaips final projection of Western dominanee. We maly be looking not just at a new but at a perfected form of imperialism. It is a form that may be impossible to set aside because everyone who might set it aside will be made complicit in it to an extent that prevents its overthrow.

These apocalyptic announcements are made not to preempt but to initiate a conversation that the January issue seems to circumvent. Is the bond between culture and imperialism, to which said bears notable witness, being severed or strengthened? It is possible that culture flows differ from economic ones, that they yield more readily to crosscurrents, eddics, intersections, symbolic exchanges, and diasporic ambivalences than economic transactions are likely to do. The idea that increasing cultural openness goes hand in hand with economic consolidation (corporate takeovers in 2000 climbed over the trilliondollar mark) appeals to the appetite for paradox, but the academy needs to provide the evidence to nourish that appetite. On the other hand, it the bond is being strengthened, the academy needs to expose this strengthening. Postcolonial analysis has to be brought up to date so that it can grapple with the fluidities and evasions of imperialisms no longer territorial. Global literary studies must give a more seemly space to the literatures of countries such as China and India-literatures with deep civilizational heritages that in these two countries alone address nearly one-half the world's people. If English literary history has ceased to be "principally about the fate of the nation" and is now "a global phenomenon" (Stcphen Greenblatt, "Racial Memory and Literary History" 53), it can only be so in a global context that takes full account of other literatures and historics.

In addition, the academy has to ask itself how best to resist the homogenizing flow of a global culture, increasingly commodified. Is it to do so by its traditional attention to difference, or should it attend also to a global exploration of social justice and 
human interconnectedness, as they are found in the world's diverse literatures?

Rey Chow notes that globalization for colonial peoples "hats always meant the evacuation of their native cultures and languages" (73). Said points to the persistence of "the assumption that 'we' can survey the world, redraw the boundaries, give sanction to (or withhold it from), some histories, languages, voices, experiences" (67). This issue of PMLA does little to dispel these anxieties.

Balachandra Rajan University of Western Ontario

\section{Legacies of Canaan and Etruria}

\section{TO THE EDITOR:}

After reading Carlos Alonso's description of PMLA's rigorous review process (Editor's Column, 116 [2001]: 9-15), I was dismayed to discover in the same issue Basem L. Ra'ad's regrettably misinformed "Primal Scenes of Globalization: Legacies of Canaan and Etruria" (89-110). By discussing Western culture's wholesale appropriation, distortion, and demonization of these accomplished ancient cultures, Ra'ad aims to establish common ground between the contemporary Middle East and the West. But in the name of healing and redress, $\mathrm{Ra}$ ' ad engages in the same "imperial" practices he decries, presenting a skewed treatment of the Hebrew Bible and of much contemporary biblical scholarship as well as promoting a fraudulent history.

$\mathrm{Ra}$ 'ad reads the biblical narrative both as a mere mass of "redacted derivatives," which is to say a patchwork of stolen Canaanite, Egyptian, Babylonian, and Philistine goods (99), and as a fixed national history that encourages the dispossession and maltreatment of non-"Israelites" (99, 101, 103). ( $R a$ 'ad's repeatedly enclosing this national name but no other in ironic quotation marks does little to convince me of the sincerity of his stated commitment to discovering human "commonality" [89].) However, as is demonstrated by contemporary literary scholars, the issue of redaction, like the longrecognized presence of mythic sources, while interesting, is hardly the whole story of Hebrew biblical narrative. Riddled with word play, ambiguity, and ellipsis, this narrative is not static but capable of transformation through time, a subtle and complex art form. (It is worth recalling here that rabbinic discussion of the biblical narrative is one of the matrices of Derridean deconstruction, whose besiegement by the academy, Ra'ad warns, "threaten[s] to erase all advances in critical analysis" [91].)

As Robert Alter points out in The Art of Biblical Narative, the nature of the Hebrew narrative is such that, far from dictating static truths, it involves the reader in a "process" of questioning meaning, making judgments that are always subject to revision, inquiring into the purposes of God ([New York: Basic, 1981] 12). From this perspective, it is not too much to say that the biblical narrative brings down to earth the cosmic battlegrounds of the older myths and in so doing provides a ground for humanizing growth, a place to wrestle, like JacobIsrael, with (the nature of the self "made in the image of") God. Certainly this is the self-expansive direction in which recent feminist biblical criticism tends. For example, in Counter-traditions in the Bible: A Feminist Approach, Ilana Pardes recuperates female voices millennially silenced by exclusionary male scholarship (Cambridge: Harvard UP, 1992). Likewise, in Three Steps on the Ladder of Writing and elsewhere, Hélène Cixous discovers in the book of Genesis a window to the unconscious, the realm of connection with all life through the mother ([New York: Columbia UP, 1993] 67).

Even at its most superficial level, the Hebrew biblical narrative insists on human interconnection. This narrative begins not with Hebrew history but with stories of the creation of all humanity. Focused though they are on the fortunes of Israel, the books of the Hebrew Bible are connected by a thread that attempts to balance the relation between power and subordination, self-interest and concern for the "other." Recall, for example, God's equalizing reminder to Israel in Amos 9.7, "Are you not as the children of the Ethiopians to me [. . .]?" Recall the prophet Nathan's parabolic rebuke to David when the king wantonly abuses his power over Uriah the Hittite (2 Sam. 11.2-12.7). Recall Abraham's bargaining with God on behalf of the Sodomites; Judah's contrite recognition of his greater guilt in the matter of Tamar; Joseph's storing up food to preserve the lives of people of all lands in a time of famine (Gen. 18.23-32, 38.26, 41.57). Recall the repeated Levitical injunction to "love your neighbor as yourself" (Lev. 19.18, 34). 